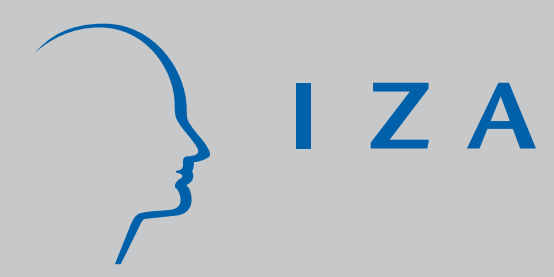

IZA DP No. 1317

Gender Equality in Educational Achievement: An East-West Comparison

Sylke Viola Schnepf

September 2004 


\title{
Gender Equality in Educational Achievement: An East-West Comparison
}

\author{
Sylke Viola Schnepf \\ $S^{3} R I$, University of Southampton, \\ University of Hamburg and IZA Bonn
}
Discussion Paper No. 1317
September 2004

\author{
IZA \\ P.O. Box 7240 \\ 53072 Bonn \\ Germany \\ Phone: +49-228-3894-0 \\ Fax: +49-228-3894-180 \\ Email: iza@iza.org
}

\begin{abstract}
Any opinions expressed here are those of the author(s) and not those of the institute. Research disseminated by IZA may include views on policy, but the institute itself takes no institutional policy positions.

The Institute for the Study of Labor (IZA) in Bonn is a local and virtual international research center and a place of communication between science, politics and business. IZA is an independent nonprofit company supported by Deutsche Post World Net. The center is associated with the University of Bonn and offers a stimulating research environment through its research networks, research support, and visitors and doctoral programs. IZA engages in (i) original and internationally competitive research in all fields of labor economics, (ii) development of policy concepts, and (iii) dissemination of research results and concepts to the interested public.
\end{abstract}

IZA Discussion Papers often represent preliminary work and are circulated to encourage discussion. Citation of such a paper should account for its provisional character. A revised version may be available directly from the author. 


\section{ABSTRACT \\ Gender Equality in Educational Achievement: An East-West Comparison*}

Data on educational access show gender parity of pupils attending primary and secondary schools in transition countries. The first aim of this analysis is to examine whether the gender balance in educational access translates also into gender equality in educational achievement. There are several and very recent international surveys available measuring pupils learning achievement and functional literacy in schools. These surveys are typically analysed in isolation from each other even though they are very different in their design. The second aim of this paper is to evaluate whether we find a robust pattern on gender equality in achievement across different sources: the Trends in International Maths and Science Study (TIMSS), the Programme of International Student Assessment (PISA) and the Programme of International Reading Literacy Study (PIRLS). Besides a comparison of gender differences in mean achievement for transition and OECD countries we discuss alternatives for translating achievement scores into something easily understood. In addition, differences in boys' and girls' achievement distributions and determinants of gender inequality will be examined.

JEL Classification: I21, J16, J24

Keywords: $\quad$ education, gender inequality, Central and Eastern Europe, PISA, TIMSS, PIRLS

Sylke Viola Schnepf

Southampton Statistical Sciences Research Institute

University of Southampton

Southampton SO17 1BJ

United Kingdom

Email: svs@soton.ac.uk

\footnotetext{
* We acknowledge joint unpublished work with and very helpful comments by John Micklewright. Thanks are also due to participants of the ESPE conference (Bergen, Norway in June 2004) for comments.
} 


\section{$1 \quad$ Introduction}

Gender equality in education is one of the preconditions for women's and men's equal opportunities in the labour market. The former communist commitment to education was accompanied by women's relative equal access to education based on the expectation that women would come to build half of the labour force. Additionally, central planning of education characterized by the standardisation of teacher training, school curricula and text books ensured equity in access, especially for rural children and girls. (Laporte and Schweitzer 1994)

However, the onset of transition led to important changes of educational systems in CEE. The shrinking spending on education and rising income inequality paired with increasing poverty might have had a negative influence on equity in educational outcomes. In addition, there is some evidence for women's higher vulnerability in the transition process from plan to market compared to that of men (Brainerd 2000, Pailhe 2000, World Bank 2000a, Newell 2001) which could have resulted in a deterioration of gender equality in education during the system change.

Even though there is some reasoning for women's worse status quo in education today, data on net enrolment ratios (NER) ${ }^{1}$ for primary and secondary education ${ }^{2}$ (our levels of analysis in this paper) given in Table A1 in the Appendix reveal the existence of gender parity in educational access in transition countries.

However, quantitative balances in educational access do not necessarily imply that gender equality is achieved in terms of educational achievement that refers to educational outcomes like ability or 'functional literacy' (the ability to function in modern society). This equality of learning achievement is important since it is related to gender equal job opportunities and earnings.

The first aim of this paper is to examine whether the gender balance in educational access translates also into gender equality in educational achievement in and between transition countries.

For examining educational achievement we can make use of recent international surveys of learning achievement of children and functional literacy. These surveys focus on what people actually know or can do. However, which achievement survey to use? Each

\footnotetext{
${ }^{1}$ NER is the number of pupils in the theoretical age group for a given grade/level of education enrolled in that level expressed as percentage of the total population in that age group.

${ }^{2}$ Results are different once tertiary education is concerned. During transition enrolment rates in tertiary education have risen steadily in all CEE sub-regions with the exception of Central Asia and the Caucasus. In general, female tertiary enrolment has risen faster than male enrolment, which is often captured by the term 'feminisation of higher education'. (UNICEF 2002, UNESCO 2003a)
} 
survey aims to assess something different (e.g. maths or reading) or to assess knowledge in a different way (e.g. in relation to an 'international' curriculum versus the ability to apply knowledge in everyday settings) and uses different methods for assessment (more open-ended or multiple-choice questions). These variations between surveys are very likely to impact upon gender results in educational achievement. Hence, a rounded picture of educational achievement of boys and girls requires the surveys' results to be compared. But each survey is typically analysed in isolation with no consideration as to whether its results support or contradict those from another. The second aim of this paper is to pull together the evidence from three different surveys to see if a robust picture exists of gender equality in achievement and literacy in transition countries. We also compare Central and Eastern European (CEE) countries with pre-1990s OECD countries (i.e. not including those in CEE) as a yardstick in order to find out whether transition countries are special regarding their pattern of gender equality in educational achievement.

The remainder is as follows. Section 2 briefly introduces to the three surveys we draw on: Trends in International Maths and Science Achievement (TIMSS), Program of International Student Assessment (PISA) and Progress in International Reading Literacy Study (PIRLS). All surveys focus on children in compulsory schooling. Section 3 compares gender inequalities in educational achievement between countries, regions, subjects and surveys. Since achievement scores of all surveys lack a simple concept of interpretation, we discuss two alternatives for making gender gaps in achievement scores meaningful in Section 4. Whether gender differences in mean achievement scores derive from greater gender differences at the top or the bottom of the achievement distribution is the focal point of Section 5. Section 6 discusses the impact of socio-economic background on gender differences in achievement. Section 7 concludes.

\section{$2 \quad$ Data}

Table 1 lists the data we use from the different surveys ${ }^{3}$ and the transition countries covered. All surveys relate to children in compulsory schooling and are recent pertaining to 1995, 1999, 2000 and 2001. While PIRLS focused on primary school children aged 9-10 years, TIMSS and PISA covered children in secondary school. PISA data is based on pupils who are 15 years old, TIMSS covered $7^{\text {th }}$ and $8^{\text {th }}$ graders. The surveys' sample designs involve the selection of a sample of schools and then a single class (TIMSS and PIRLS) or a random sample (PISA) of pupils within each school.

\footnotetext{
${ }^{3}$ Details on the surveys can be found in their reports: Mullis et al (2000a), Mullis et al (2003), OECD (2001) and OECD and UNESCO (2003).
} 
The three surveys differ considerably so that the choice of the survey for examining gender differences in educational achievement might impact upon the results. Different surveys covered different subjects, assessed different types of achievement and collected information differently. PISA and PIRLS assessed reading ability; PISA and TIMSS cover additionally maths and science knowledge. The general notion tells us that boys perform better in maths and girls in reading.

PISA aims to measure broad skills, trying to look at how students would be able to use what they have learned in 'real-life situations'. PIRLS measured primary school children's reading and understanding capability of written texts. In contrast to PISA and PIRLS, TIMSS focused on assessing a mastery of internationally agreed curricula. These different approaches for measuring achievement shape also the content of the subject area emphasised in surveys. TIMSS science assessment places great emphasis on physics where boys perform generally better than girls. PISA focuses on life sciences where girls seem to fair better.

Also the differences in how information is collected might lead to gender sensitive results. TIMSS uses more multiple-choice questions (about two-thirds of the TIMSS questions were multiple choice in 1999) than PIRLS and PISA that apply open-ended questions to a greater extent. Survey results suggest that girls fare generally better with openended questions while tests with more multiple-choice items favour boys. (OECD 2002)

In addition, surveys differ regarding their application of aggregation methods for transferring results into the final analysed achievement measure. Survey organisers do not report the sensitivity of results to the choice of model but Brown and Micklewright (2003) show with TIMSS data that this is not a trivial issue.

In short, there seems ample reason for comparing results across the different surveys rather than relying on a single source.

Table 1 presents the transition countries that participated in each survey. The surveys cover 13 of 27 countries of the former Soviet bloc. In particular, the countries in the Caucasus and Central Asia are excluded. Unfortunately, these regions differ wildly in cultural, geographic and economic terms from the countries covered in our analysis. ${ }^{4}$

\footnotetext{
${ }^{4}$ With the onset of transition in the Caucasus and Central Asia educational expenditure plummeted, the purchasing power of teachers' wages decreased, simultaneously the population of basic-school-age children increased (UNICEF 2002) and traditional values re-emerged (Tablyshalieva 1999). These differences are very likely to impact on gender equality in educational achievement.
} 
Table 1: Coverage of CEE countries by educational surveys

\begin{tabular}{|c|c|c|c|}
\hline & TIMSS & PISA & PIRLS \\
\hline \multicolumn{4}{|l|}{ Description of survey } \\
\hline Date of collection & 1995, 1999 & 2000 & 2001 \\
\hline Age group & $\begin{array}{l}7^{\text {th }} \text { and } 8^{\text {th }} \text { graders } \\
\text { (14 year olds) }\end{array}$ & 15 year olds & $\begin{array}{c}4^{\text {th }} \text { graders ( } 9 \text { to } \\
10 \text { year olds) }\end{array}$ \\
\hline Subjects covered & Maths and science & $\begin{array}{l}\text { Reading, maths } \\
\text { and science }\end{array}$ & Reading \\
\hline Sample size per country & 3,800 at each grade & 5,700 & 4,300 \\
\hline \multicolumn{4}{|c|}{ Countries covered by survey } \\
\hline Albania & & $\mathrm{X}$ & \\
\hline Bulgaria & $\mathrm{X}$ & $\mathrm{X}$ & $\mathrm{X}$ \\
\hline Czech Republic & $\mathrm{X}$ & $X$ & $\mathrm{X}$ \\
\hline Hungary & $X$ & $\mathrm{X}$ & $\mathrm{X}$ \\
\hline Latvia & $\mathrm{X}$ & $\mathrm{X}$ & $\mathrm{X}$ \\
\hline Lithuania & $\mathrm{X}$ & & $\mathrm{X}$ \\
\hline Macedonia, Republic of & $X$ & $\mathrm{X}$ & $X$ \\
\hline Moldova & $\mathrm{X}$ & & $\mathrm{X}$ \\
\hline Poland & & $\mathrm{X}$ & \\
\hline Romania & $\mathrm{X}$ & $\mathrm{X}$ & $\mathrm{X}$ \\
\hline Russian Federation & $\mathrm{X}$ & $\mathrm{X}$ & $\mathrm{X}$ \\
\hline Slovak Republic & $\mathrm{X}$ & & $\mathrm{X}$ \\
\hline Slovenia & $X$ & & $\mathrm{X}$ \\
\hline
\end{tabular}

Note: PISA data refer to the year 2000 with the exception of Albania, Bulgaria and Macedonia, where data were collected in 2002 in the PISA Plus round.

The surveys' data on school children cannot shed light on gender equality of children not enrolled in school or attending special schools. This should not be of a great concern given gender neutrality of educational enrolment rates in transition countries covered by surveys (see Table A1 in the appendix). Nevertheless, educational attainment might be partly gender sensitive once we focus on minorities. We cannot cover e.g. Roma girls in Romania who tend to drop out of school earlier than boys or gender differences in achievement of disabled children and of the much higher share of ethnical minorities attending special schools (UNESCO 2003b) since special schools are normally not covered by surveys.

\section{Mean achievement and gender inequality in CEE countries compared to OECD countries}

We start the discussion of gender inequality in educational achievement with the focus on the most recent survey PIRLS that covers reading achievement of primary school children who where born when the communist area had already ended. Figure 1 presents $4^{\text {th }}$ graders' average achievement in reading on the $\mathrm{x}$-axis and gender differences in these reading mean scores on the $y$-axis for OECD and CEE countries. 
Macedonia the CEE country with lowest pupils' achievement shows similar achievement to the OECD country Turkey. Among the high achieving countries we find equally CEE and OECD countries like Sweden and Bulgaria ${ }^{5}$.

The negative value on the gender differences axis for all countries means that girls are performing better than boys. (Consistently in this paper, a negative value of gender differences shows a lower performance of boys, a positive value of gender differences refers to a better achievement of boys.) Similarly to mean achievement, CEE countries do not seem to differ greatly from OECDs once we focus on gender differences. Highest gender differences appear in New Zealand, Moldova and Bulgaria. Boys are much less disadvantaged in Italy, France, Russia, Czech Republic and Germany. For all countries gender differences in reading are significant. (Mullis et al 2003)

Figure 1: PIRLS mean reading achievement and gender differences in reading $\left(4^{\text {th }}\right.$ graders)

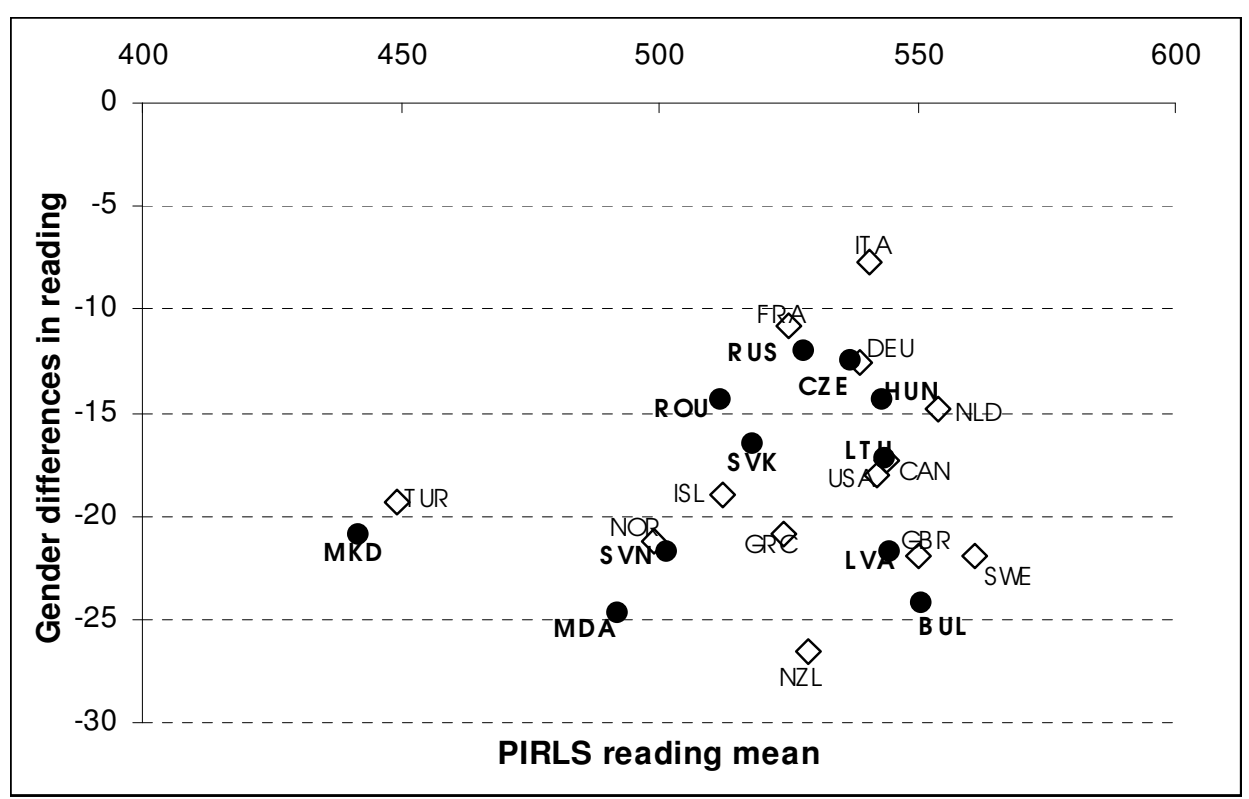

Source: PIRLS report. Note: Gender differences in average achievement are negative if boys perform worse than girls.

Until now we focused solely on the subject reading. Do we find different patterns once we change the subject of the survey? Figure 2 places countries again on the achievement and gender differences axes but this time focusing on $8^{\text {th }}$ graders' maths achievements in TIMSS.

\footnotetext{
${ }^{5}$ For a detailed comparison of educational achievement between CEEC and OECD countries across different educational surveys see Micklewright and Schnepf, 2004.
} 
Figure 2: TIMSS mean maths achievement and gender differences in maths (8th graders)

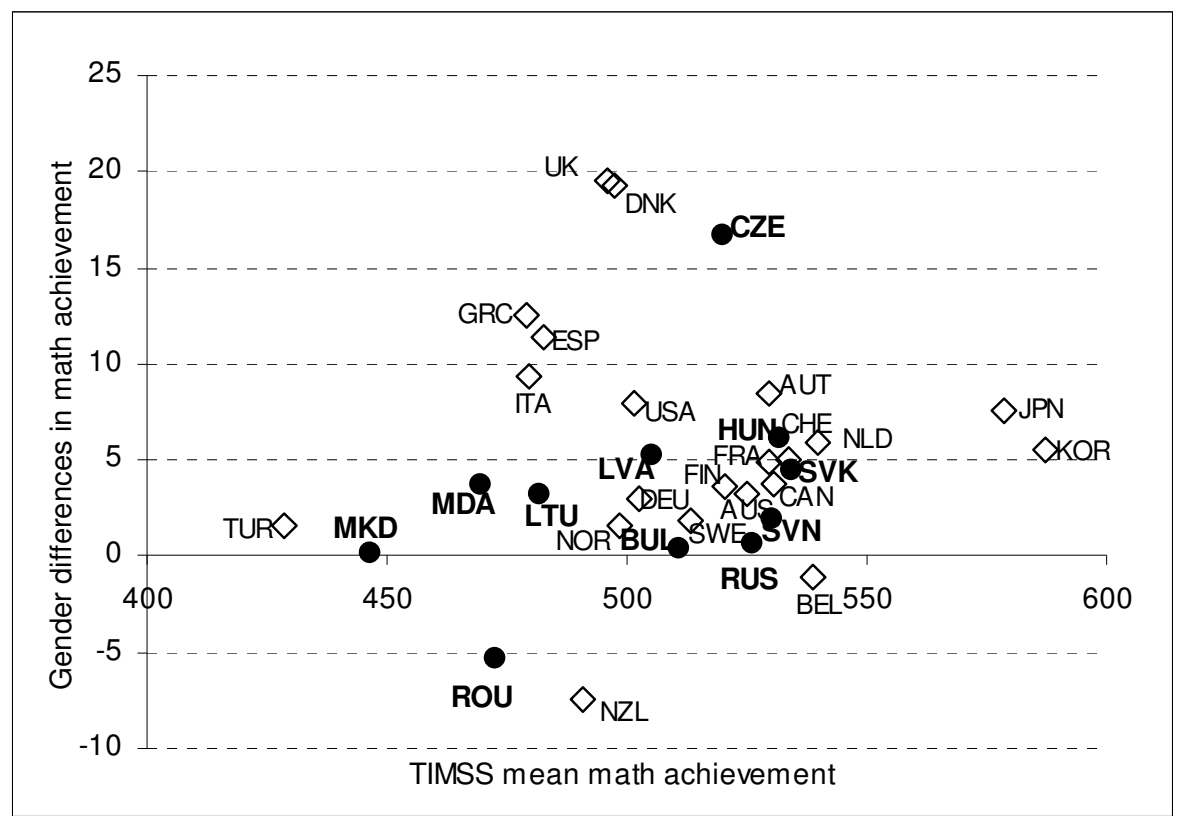

Source: author's calculations. Note: data on Austria, Denmark, France, Germany, Greece, Norway, Spain, Sweden and Switzerland refer to new scale scores of 1995, data on all other countries refer to 1999.

With the exception of Romania and New Zealand gender differences in maths average scores are now positive indicating that in general boys fare better than girls in this subject. However, gender differences seem to be rather low compared to PIRLS, since boys' maths achievement is often not higher than 10 points compared to that of girls. Only in the Czech Republic, Denmark and the UK boy's educational achievement scores are on average almost 20 points higher and significantly better than those of girls. (Mullis et al 2000a) With the exception of the Czech Republic girls' educational disadvantage seems to be slightly lower in transition than in OECD countries.

In addition to results on PIRLS reading and TIMSS maths, Table 2 presents the overall picture of gender differences in mean achievement scores across all surveys and subjects. It is important to note that point differences in mean achievement are not directly comparable between surveys given the great differences in surveys' design described in Section 3. Nevertheless, in order to examine whether surveys show robust results we can examine the ranking of countries on gender differences and the correlation of gender differences in achievement scores between surveys. Gender differences are displayed for post-communist countries and are averaged for these and for a similar group of OECD countries for each survey. Light grey fields (negative values) indicate a significant (5 percent level) advantage of girls' achievement over that of boys. Dark grey fields (positive values) show that boys' 
achievement is significantly better than that of girls. Countries are ordered by gender differences in reading.

Table 2: Gender differences in surveys' mean achievement

\begin{tabular}{|c|c|c|c|c|c|c|}
\hline & PISA & PIRLS & PISA & TIMSS & PISA & TIMSS \\
\hline & Reading & Reading & Maths & Maths & Science & Science \\
\hline Albania & - $58(3.8)$ & & - $18(5.7)$ & & $-22(5.3)$ & \\
\hline Latvia & - $53(4.2)$ & $-22(3.4)$ & $6(5.3)$ & $5(4.5)$ & $-23(5.4)$ & $15(4.0)$ \\
\hline Macedonia & $-50(3.2)$ & $-21(3.6)$ & $-3(4.7)$ & $0(4.5)$ & $-16(4.4)$ & $1(4.6)$ \\
\hline Bulgaria & $-47(5.6)$ & $-24(3.6)$ & $-4(7.1)$ & $0(5.5)$ & $-5(6.1)$ & $14(6.2)$ \\
\hline Moldova & & - $25(4.0)$ & & $3(4.1)$ & & $11(5.4)$ \\
\hline Slovenia & & $-22(2.8)$ & & $1(3.6)$ & & $13(3.7)$ \\
\hline Lithuania & & - $17(2.7)$ & & $3(4.0)$ & & $21(4.6)$ \\
\hline Slovakia & & - $16(3.0)$ & & $5(3.6)$ & & $21(4.5)$ \\
\hline Russia & - 38 (2.9) & $-12(4.3)$ & $-2(4.3)$ & $1(3.3)$ & $-14(4.5)$ & $20(3.9)$ \\
\hline Czech Republic & - $37(4.7)$ & $-12(2.8)$ & $12(5.2)$ & $17(5.0)$ & $1(5.1)$ & $33(4.8)$ \\
\hline Poland & - $36(7.0)$ & & $5(3.5)$ & & $6(7.4)$ & \\
\hline Hungary & - $32(5.7)$ & - $14(2.1)$ & $7(6.2)$ & $6(3.7)$ & $-2(6.9)$ & $25(4.2)$ \\
\hline Romania & $-14(6.0)$ & $-14(3.8)$ & $-11(7.3)$ & $-5(4.7)$ & - $14(6.6)$ & $7(5.4)$ \\
\hline CEE average & $-41(3.4)$ & - $19(3.5)$ & $-1(3.5)$ & $3(5.0)$ & $-10(3.1)$ & $19(5.3)$ \\
\hline OECD average & $-32(2.0)$ & - $17(1.6)$ & $12(2.2)$ & $7(2.8)$ & $2(2.2)$ & $21(3.0)$ \\
\hline
\end{tabular}

Source: Survey reports, author's calculations. Note: Countries are ordered by gender differences in PISA and PIRLS reading. Standard errors are given in parenthesis. Bold figures show that gender differences are significant on a 5 percent level. OECD countries are for PISA and TIMSS: Austria, Belgium, Denmark, Finland, France, Germany, Greece, Italy, Korea, Netherlands, Norway, Spain, Sweden, Switzerland, USA and UK. For PIRLS OECD countries are France, Germany, Greece, Iceland, Italy, Netherlands, Norway, Sweden, USA and UK. Standard errors for countries are taken from survey reports, standard errors for the country groups CEE and OECD are calculated by taking survey design into account (clustering and weights). OECD and CEE countries' gender differences refer to the unweighted average.

Similarly to PIRLS results discussed with Figure 1 (and displayed in column 3 of Table 2), we find also for PISA a significant advantage of girls over boys in reading for all CEE countries. The correlation of gender differences between PISA and PIRLS is 0.65 if we take all OECD and CEE countries covered in both surveys into account. (see Table A2 in the Appendix).

Gender differences in OECD countries are not significantly different from that in CEE countries for PIRLS. However, regarding PISA results only Hungary and Romania show a similarly low gender difference in reading achievement than OECD countries. On average in this survey girls' educational advantage is significantly greater in transition than in OECD countries.

Column 3 and 4 of Table 2 compare TIMSS and PISA results regarding the subject maths. Consistently for both surveys the Czech Republic is the only post-communist country where girls' average maths achievement is significantly lower than that of boys. In all other CEE countries female pupils' knowledge of mathematics is rather equal to that of boys. An outlier is Albania, where girls fare significantly better than boys and where boys` educational 
inequalities are large compared to other CEE countries and across all subjects of the survey PISA. Average OECD and CEE country figures indicate that transition countries are more successful in maintaining gender equality than Western industrialised countries for PISA while country group differences are not significant for TIMSS.

The correlation coefficient of gender differences in mean maths scores is moderate with 0.59 for all CEE and OECD countries covered in both surveys.

An important result deriving from the comparison of maths and reading achievement by gender is that girls' disadvantage in maths is obviously much smaller than boys' disadvantage in reading.

The last two columns of Table 2 compare gender differences in science for PISA and TIMSS. It seems contradictory, that gender differences are generally positive for TIMSS indicating girls' disadvantage and partly negative for PISA indicating boys ' disadvantage. These counter-intuitive results in gender disadvantages might be due to PISA's greater emphasis on life science, where females tend to perform well, while TIMSS emphasises physics, where males generally perform better. Additionally, the higher proportion of openended questions in which females do generally better and the emphasis on application of knowledge in PISA is probable to account for females' better achievement. (OECD 2001) Even though PISA and TIMSS results seem to be contradictory in terms of negative or positive gender differences, the correlation coefficient of gender differences in mean maths scores is again moderate with 0.56 (Table A2). This shows agreement between surveys in the way that a higher boys' educational disadvantage with PISA in one country is related to a lower boys' advantage in TIMSS in the same country.

Taken all subjects together, girls' advantage in transition countries seems to be generally higher than that in the West. Girls in post-communist countries fare in three measures better than boys (PISA and PIRLS reading, PISA science) and only in one measure worse than boys (TIMSS science). In OECD countries girls show significantly better results than their male counterparts in only two measures (PISA and PIRLS reading) while they are in a significant disadvantage in three measures (PISA and TIMSS maths, TIMSS science). This shows that girls in transition countries are not facing high educational disadvantage today as assumed before but that relative to boys they fare even better in CEE than in OECD countries regarding their educational achievement.

Results of surveys seem to be quite robust. Correlation coefficients around 0.6 indicate a moderate agreement between surveys. In addition, survey results are similar for single countries. In the Czech Republic throughout all surveys and measures girls seem to be in a 
greater disadvantage compared to other transition countries, since female pupils show relative low educational advantage over boys in reading and PISA science and appear to have much lower educational achievements than boys in maths and TIMSS science. On the other hand, gender equality seems to be consistently great in Romania given different survey results.

\section{$4 \quad$ How to interpret gender differences?}

What are the implications of gender differences described in Table 2 in terms of something readily understood? The achievement scores lack a natural metric. What does it mean that female pupils' average achievement in PISA reading is 58 test scores higher than that of boys in Albania? Is this a big or small gender difference? This section discusses the importance of gender differences by offering two different possibilities for interpreting gender disadvantage.

\subsection{Gender differences expressed in school year progression}

For interpreting gender differences we can make use of variation in mean achievement between different grades. Figure 3 plots the distribution of scores in Albania for boys and girls (grey lines - both only for pupils in $10^{\text {th }}$ grade) and $9^{\text {th }}$ and $10^{\text {th }}$ graders (black lines - both genders) for PISA reading separately. Average achievement differences between the both grades are 56 reading points. This is roughly equivalent to mean achievement differences between boys and girls. Hence, on average Albanian girls are about one year ahead of their male counterparts in reading achievement.

Table A3 in the Appendix displays the disadvantage of gender expressed in school years for subjects of PISA and TIMSS surveys for these CEE countries where gender differences and grade differences are significant. Regarding reading achievement, girls are almost two school years ahead of boys in the Czech Republic ${ }^{6}$, one and a half year in Macedonia and Russia and about one year in Latvia and Hungary. In TIMSS maths girls face educational disadvantage similar to half a year of school progression only in the Czech Republic. Girls' disadvantage is much higher for TIMSS science since they are about one year of schooling behind boys in the Czech Republic and Hungary.

\footnotetext{
${ }^{6}$ Even though girls' educational advantage over boys is small in the Czech Republic, it appears to be great once expressed in school progression, since differences in achievement scores between grades are rather small for PISA reading in this country.
} 
Figure 3: Kernel density distribution of PISA reading achievement in Albania by grade and gender

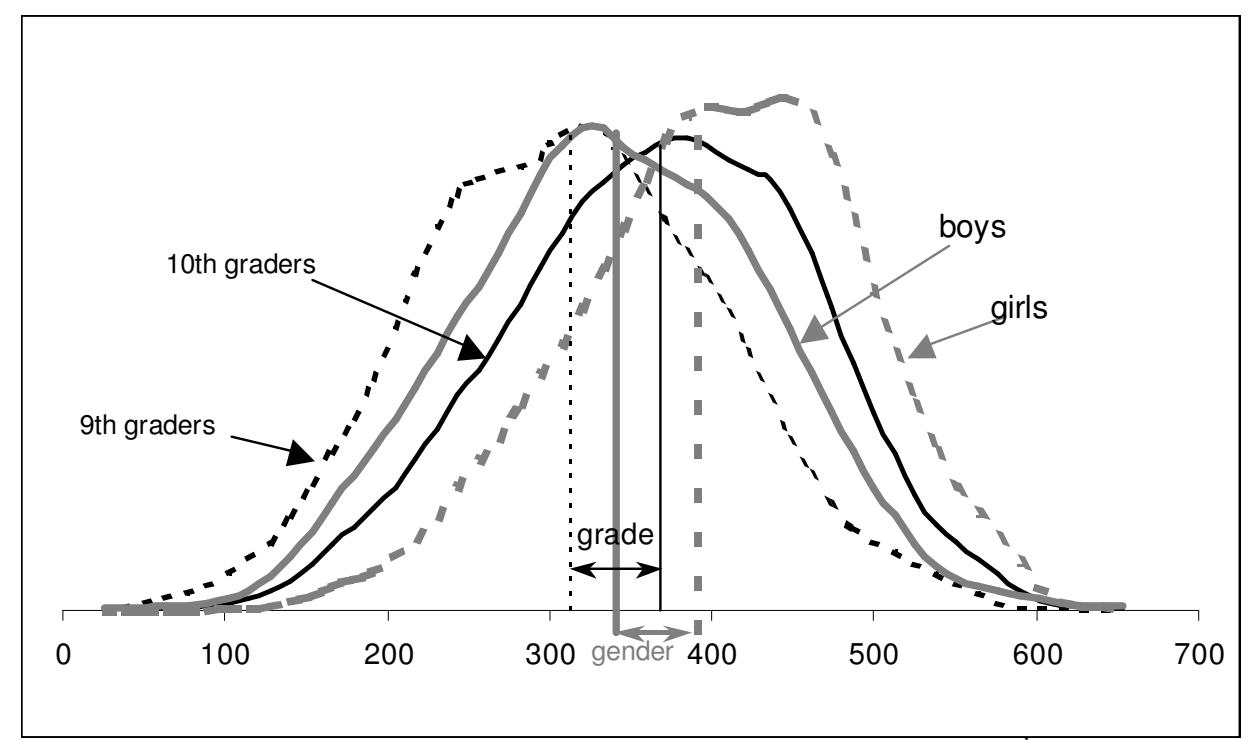

Source: author's calculation. Note: Kernel density distributions by gender refer only to $10^{\text {th }}$ graders. The sample size for pupils in $9^{\text {th }}$ grade is 1.211 , for pupils in $10^{\text {th }}$ grade 3.475 . Mean differences between $9^{\text {th }}$ and $10^{\text {th }}$ graders are 56 reading scores points. Mean differences between boys and girls in $10^{\text {th }}$ grade are 49 reading scores points.

Even though these gender differences appear to be high they account only for a small share of educational dispersion. In PISA reading the within-country variation measured by the difference between the $95^{\text {th }}$ and $5^{\text {th }}$ percentile ${ }^{7}$ is 324 points for Albania. Given the grade achievement differences of 56 points, the range between the $5^{\text {th }}$ and $95^{\text {th }}$ percentiles in Albania is almost six times the progression in mean scores between the grades. Apparently, gender differences in reading achievement - just being 'worth' one year in terms of grade progression - are relatively low compared to the overall educational dispersion in that country. Also in PIRLS reading and TIMSS science achievement differences between pupils in the $5^{\text {th }}$ and $95^{\text {th }}$ countries' percentile are generally between eight to twenty times higher than the significant gender differences in achievement. For all surveys and countries within-country differences in educational achievement are greater than between-country differences. This indicates that there are many factors besides gender impacting upon achievement results.

\subsection{Gender differences expressed in absolute educational disadvantage}

Another method for interpreting gender differences is to compare pupils' absolute educational disadvantage. PISA organisers judge pupils below a certain achievement score (called 'literacy level 2') to be 'unable to solve basic reading tasks, such as locating straightforward information, making low-level inferences of various types, working out what a well-defined 
part of a text means and using some outside knowledge to understand'. (OECD 2000) The share of those students who cannot cope with simple reading tasks is of a great concern since it reveals the profound shortcomings of educational systems to provide necessary educational skills for all. ${ }^{8}$

Figure 4: Percentage of female and male pupils below PISA reading level 2 (15 year-olds)

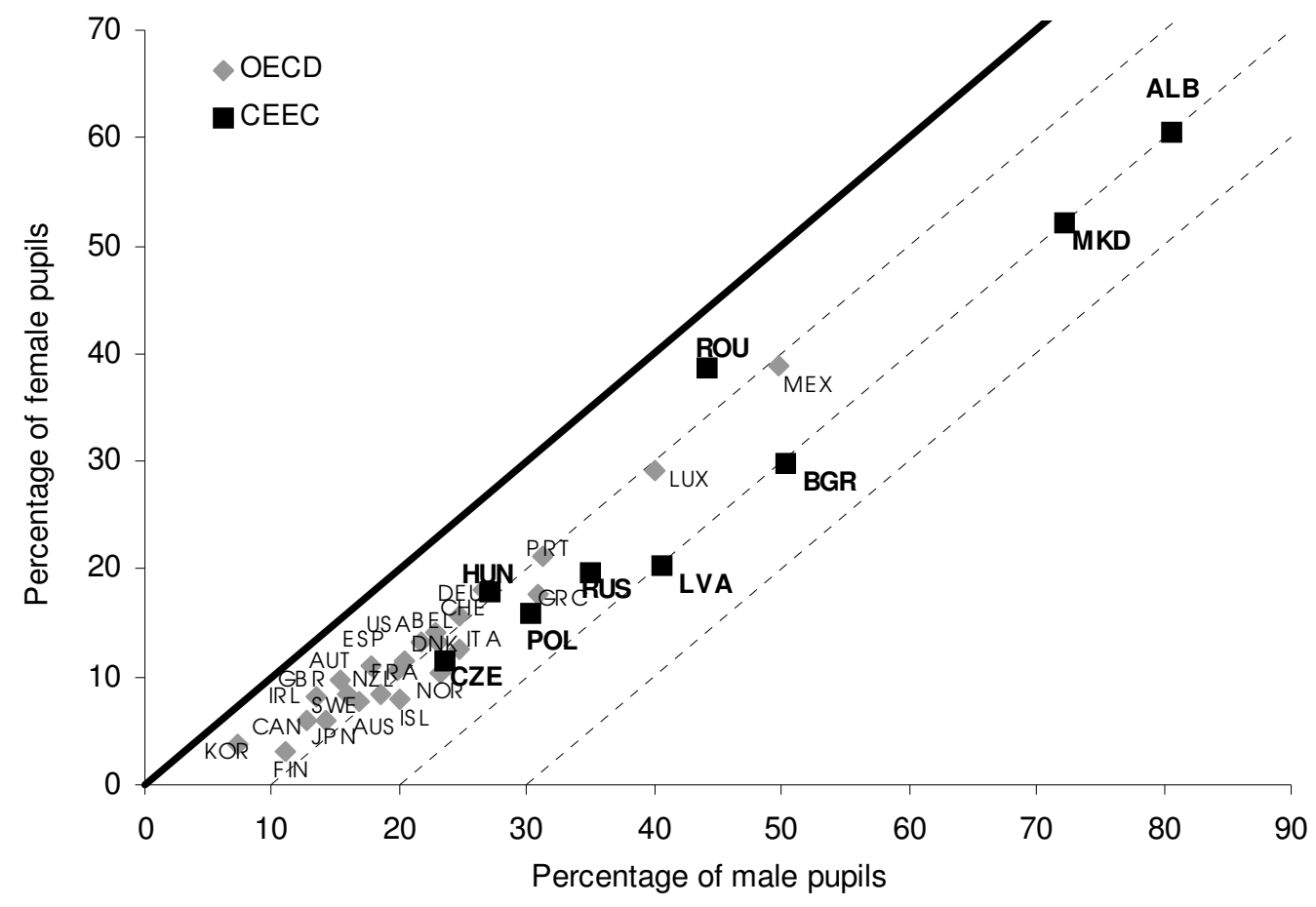

Source: OECD and UNESCO 2003, own calculations.

Figure 4 presents a scatter plot of percentages of male (x-axis) and female pupils (yaxis) below PISA reading literacy level 2. The solid line shows where countries would be situated in case the same share of girls and boys showed equally low average achievement in reading. All countries have a higher share of boys than girls with serious deficiencies in reading abilities.

OECD and CEE countries show different patterns of low achievement and gender discrepancy. In OECD countries much lower shares of pupils show high deficiencies in reading ability and differences between the male and female share of students performing below level 2 are generally not higher than 10 percent.

\footnotetext{
${ }^{7}$ As Figure 3 illustrates, scores are approximately normal. Our results are not sensitive to our choice of measures of dispersion.

${ }^{8}$ The focus on the share of girls and boys below a certain benchmark of educational achievement does not only capture mean gender differences in achievement scores but also gender differences in educational dispersion. The standard deviation of boys' educational achievement is generally greater than that of girls (see Section 5) so that also with gender equal mean achievement a higher share of boys would fall below the benchmark than girls.
} 
The greater national share of low performing students in transition countries seems also to be related to higher gender differences between those pupils with low educational achievements. In about half of transition countries gender differences amount up to 20 percent (see Table A4 in Appendix). Every second 15 year-old male in Bulgaria and two of three male pupils in Macedonia and Albania face serious deficiencies in reading literacy while girls disadvantage remains much lower. In the countries Latvia, Poland and Russia still about twice as many boys as girls are unable to solve basic reading tasks. This amount of gender differences in transition countries appears to be large given that all children attend compulsory schooling.

\section{$5 \quad$ Where do gender differences in average achievement derive from?}

This section looks at the statistical explanation for gender differences in mean achievement and does this by examining gender differences across the whole achievement distribution. We ask at which part of the achievement distribution gender differences are greatest: at the top or at the bottom. This question is of interest since gender differences in mean achievement driven by high gender differences among the worse performers is of a much greater concern than gender differences driven by large gender differences among the best performers. It might be argued that educational disadvantage determined by topperformers is even a good sign showing that educational systems manage to promote also those children with high ability. On the other hand, high educational disadvantage among lowest performers indicates a lack of schools' capability to help children with learning problems successfully.

We start the comparison of gender-specific educational achievement distribution by focusing on gender differences in educational dispersion. Literature shows that males are more variable in cognitive abilities than females. (Hedges and Friedman 1993) Do we find the same gender pattern once focusing on 3 different surveys covering 7 measures of cognitive ability for transition and OECD countries? Table 3 presents the ratio of boys to girls' educational dispersion (measured by the difference between the 95th and 5th percentile) for all measures and surveys. We compare transition countries to Italy, Sweden and the UK. Similar to Table 2 light grey fields indicate a significantly higher mean achievement for girls, dark grey fields for boys.

Results show indeed that educational disparities are higher for boys than for girls consistently across measures, surveys and in almost all transition ${ }^{9}$ and the three pre-1990s

\footnotetext{
${ }^{9}$ In only four cases educational dispersion is equal or neglectable smaller for boys than for girls: Latvia for PIRLS, Bulgaria for PISA science and Romania for PISA reading and TIMSS science.
} 
OECD countries. Transition countries and the three Western European countries show a relative similar pattern with boys' educational dispersion being up to 11 percent higher than those of girls.

We might expect that higher mean achievement is related to lower educational dispersion. But this is not the case - at least not regarding gender differences. In all subjects where boys fare significantly better than girls (shaded dark grey) they still show higher educational dispersion than their female counterparts.

Table 3: Boys to girls ratio of the difference between achievement scores in the 95th and 5th percentile

\begin{tabular}{|c|c|c|c|c|c|c|c|}
\hline & $\begin{array}{c}\text { PISA } \\
\text { Reading }\end{array}$ & $\begin{array}{c}\text { PIRLS } \\
\text { Reading }\end{array}$ & $\begin{array}{c}\text { PISA } \\
\text { Maths }\end{array}$ & $\begin{array}{l}\text { TIMSS } \\
\text { Maths }\end{array}$ & $\begin{array}{c}\text { PISA } \\
\text { Science }\end{array}$ & $\begin{array}{l}\text { TIMSS } \\
\text { Science }\end{array}$ & $\begin{array}{l}\text { Surveys } \\
\text { Average }\end{array}$ \\
\hline Slovakia & & 1.06 & & 1.10 & & 1.10 & 1.09 \\
\hline Poland & 1.09 & & 1.10 & & 1.05 & & 1.08 \\
\hline Czech & 1.17 & 1.06 & 1.10 & 1.02 & 1.09 & 1.03 & 1.08 \\
\hline Slovenia & & 1.06 & & 1.07 & & 1.08 & 1.07 \\
\hline Latvia & 1.09 & 0.99 & 1.04 & 1.08 & 1.12 & 1.09 & 1.07 \\
\hline Macedonia & 1.10 & 1.01 & 1.09 & 1.04 & 1.11 & 1.04 & 1.07 \\
\hline Moldova & & 1.10 & & 1.06 & & 1.04 & 1.07 \\
\hline Russia & 1.08 & 1.05 & 1.04 & 1.09 & 1.05 & 1.04 & 1.06 \\
\hline Bulgaria & 1.03 & 1.09 & 1.10 & 1.04 & 0.99 & 1.07 & 1.05 \\
\hline Lithuania & & 1.02 & & 1.03 & & 1.11 & 1.05 \\
\hline Albania & 1.07 & & 1.06 & & 1.03 & & 1.05 \\
\hline Hungary & 1.03 & 1.07 & 1.01 & 1.08 & 1.02 & 1.07 & 1.05 \\
\hline Romania & 1.00 & 1.07 & 1.01 & 1.08 & 1.01 & 1.00 & 1.03 \\
\hline Italy & 1.12 & 1.02 & 1.08 & 1.03 & 1.10 & 1.05 & 1.07 \\
\hline Sweden & 1.06 & 1.06 & 1.01 & 1.02 & 1.07 & 1.06 & 1.05 \\
\hline UK & 1.08 & 1.04 & 1.08 & 1.09 & 1.04 & 1.09 & 1.07 \\
\hline
\end{tabular}

Source: author's calculation. Note: the ratio is calculated by dividing boys' q95-q5 by that of girls. Countries are ordered by the average ratio across all surveys. Light grey shading indicates girls' significantly higher mean achievement, dark grey shading indicates boys' educational advantage.

Figures 5 and 6 examine the difference in boys' and girls' achievement distributions. We estimate the achievement score for each ventile by gender and divide then the boys' achievement score in one ventile through the girls' achievement score in the same ventile. The figures give this achievement ratio of boys to girls by ventile. A ratio of 1 means a gender equal achievement score in the ventile, a ratio smaller than 1 indicates that girls show a higher achievement than boys and a number greater than 1 indicates that boys show a greater achievement than girls in the ventile of their gender's distribution. 
Figure 5: Ratio of achievement scores of boys to girls by percentile for PISA reading

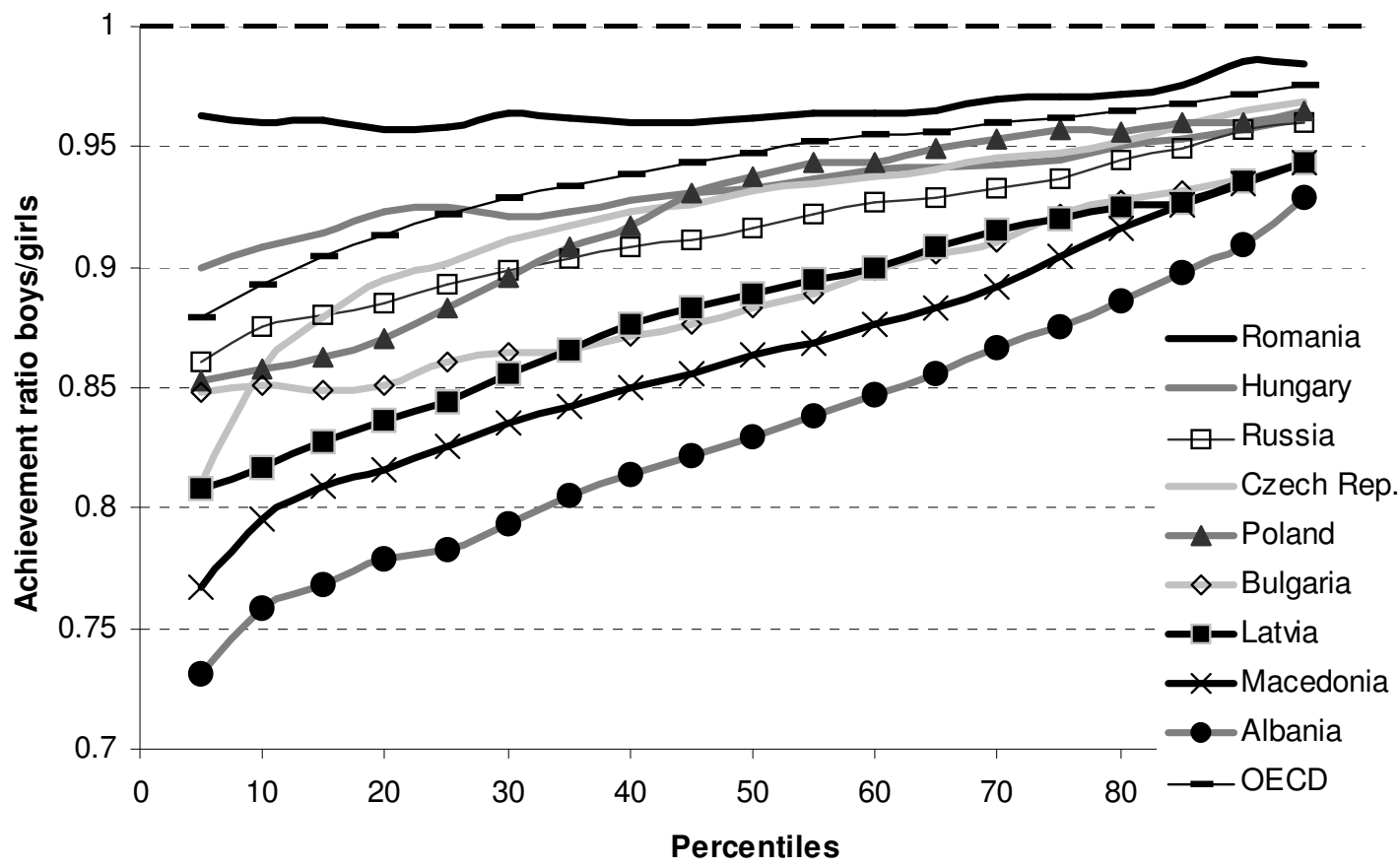

Figure 6: Ratio of achievement scores of boys to girls by percentile for TIMSS science

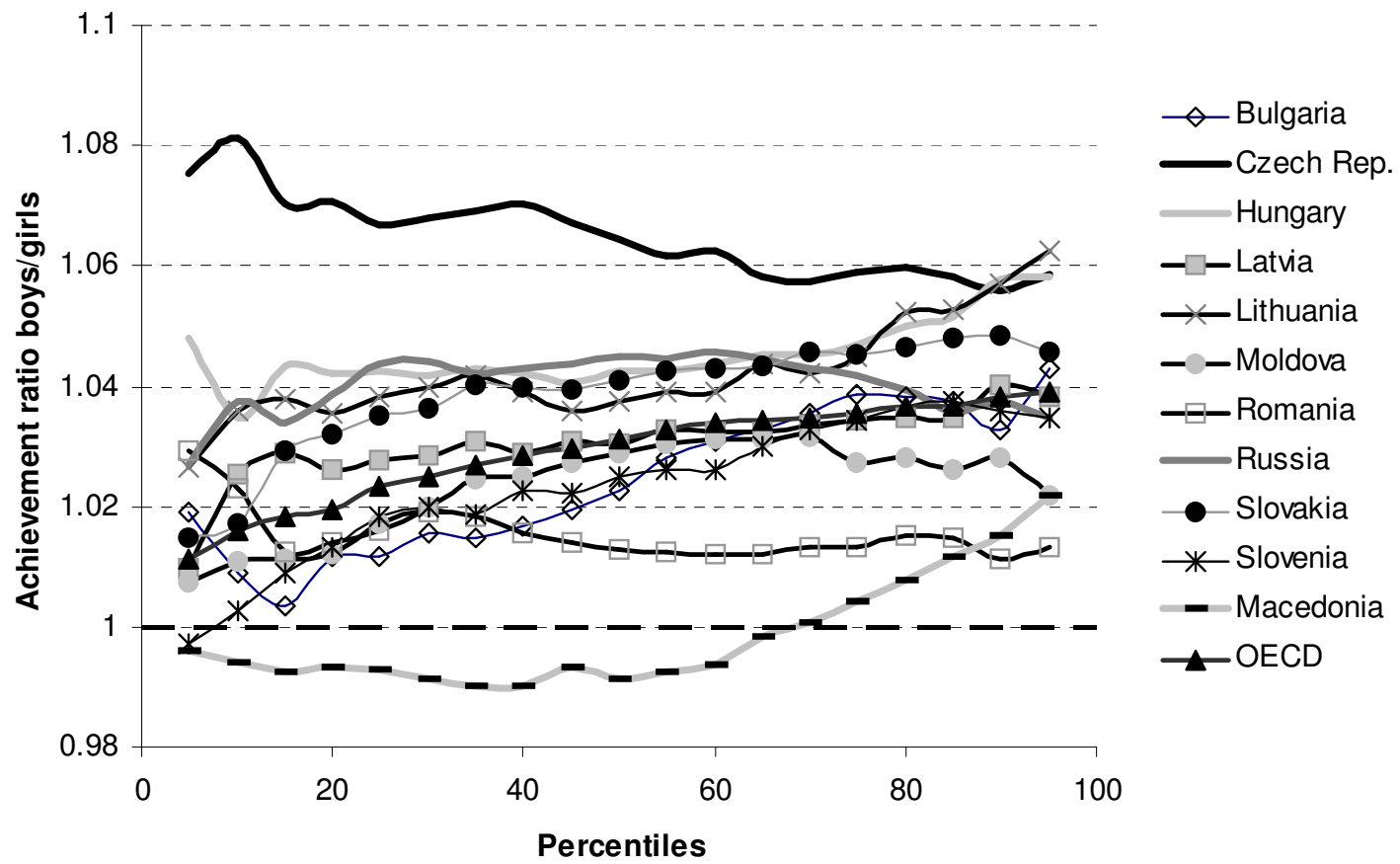


Figure 5 gives this ratio for PISA reading, a subject where on average boys fare significantly worse than girls in all OECD and transition countries. For all ventiles and countries girls' achievement scores are higher than that of boys (ratio is smaller than 1). However, the interesting result is the quite similar pattern of gender achievement differences across percentiles for all transition and the pooled OECD country sample. With the exception of Romania, gender differences in achievement are greatest at the bottom of the gender distribution. In some countries this gender gap at the bottom appears to be large. In Albania, Macedonia, Latvia and the Czech Republic boys at the very bottom of the distribution reach achievement scores that are around or more than 20 percent lower than those of worst achieving girls. In Bulgaria, Poland, Russia, Hungary and the pooled OECD sample boys in the $5^{\text {th }}$ percentile achieve about 10 to 15 percent worse achievement scores than girls situated in the bottom of their distribution.

With growing percentiles the discrepancy in achievement scores in the two different gender distributions decreases. At the $95^{\text {th }}$ percentile, the top of the achievement distribution, boys reach achievement scores that are only between 2 and 7 percent lower than those of girls.

This result indicates that mean achievement differences between boys and girls we focused on before (Table 2) derive mainly from boys' low performance at the bottom of the achievement distribution. This pattern of highest gender differences among lowest ability pupils is the same for transition and OECD countries and repeats once we focus on PIRLS reaching achievement (results not shown).

We might assume that average achievement differences between two different groups of children can generally be explained by greater discrepancies in the bottom of the two achievement distributions. Hence, in case girls achieve lower scores than boys on average we would expect to find that girls fall greatest behind boys' achievement scores also at the bottom of the distribution. Only in one survey and subject we find a relative consistent disadvantage of girls over boys in achievement: TIMSS science. Hence, Figure 6 presents gender achievement differences by ventile for this survey and subject.

However, for science achievement we find the opposite results than for reading achievement. There is a tendency that gender differences in TIMSS science achievement are not highest among the worst but highest among the best performing students (a result that confirms research by Hedges and Nowell (1995) on gender distribution in maths and science ability). In general, with increasing ventiles also girls' disadvantage in achievement increases. Hence, once focusing on science achievement girls' disadvantage is driven by the better 
performance of boys in the top of the distribution. Only in the Czech Republic the gender gap in achievement is greatest at the bottom of the achievement distribution.

Similar to TIMSS science we find also for PISA maths that gender differences are greatest among the best performing students (see Figure A1 in the appendix). In addition, this figure shows that gender equality in mean achievement in Poland, Macedonia and Bulgaria (see Table 2) is a result of boys' worse achievement in the bottom of the distribution and boys' better achievement in the top of the distribution compared to girls' distribution. Hence, the similar mean achievements for girls and boys conceal gender differences in the bottom and the top of the achievement distribution.

Taken together, once maths and science achievement is concerned girls' educational disadvantage is slightly increasing with higher ventiles. Hence, girls lower mean achievement in maths and science derive mainly from higher gender differences among best performing students. In contrast, boys' great disadvantage in reading achievement derives predominantly from large gender differences amongst low performers. Regarding reading we found for each country and for PISA and PIRLS consistently, that boys fall even considerably behind the achievement of 'worst performing' girls. This indicates that boys as the 'lowest low performers' might face serious problems to catch up with other pupils' reading skills in some transition countries. These different distributional patterns for subjects - the greater gender difference among top performers for maths and science and the greater gender difference among worst performers for reading - is similar for transition and OECD countries.

\section{Determinants of gender inequality}

Until now we compared gender $(\mathrm{G})$ inequalities in educational achievement $(A)$ across countries and surveys. We assumed that an individuals (i) achievement is dependent on gender:

(1)

$$
A_{i}=\alpha_{0}+\alpha_{1} \mathrm{G}_{\mathrm{i}}+\varepsilon_{\mathrm{i}}
$$

In general, educational production functions estimate also the impact of socioeconomic background (SE) on achievement, e.g.:

$$
A_{i}=\beta_{0}+\beta_{1} \mathrm{G}_{\mathrm{i}}+\beta_{2} \mathrm{SE}_{\mathrm{i}}+\varepsilon_{\mathrm{i}}
$$

However, as long as gender differences in achievement of school age children are concerned, there is ample reason to assume that the crude impact of gender on achievement is the same as its impact conditional on socio-economic background. First, all children tested in PISA, TIMSS and PIRLS are still in compulsory schooling, so that the sample of the children in our analysis cannot be selected depending on socio-economic background (as perhaps later on in tertiary education). Second, gender in contrast to single parenthood cannot proxy some 
other factors like socio-economic background. Parents do not have a choice of their child's gender.

We can therefore assume that $\operatorname{COV}(G, S E)=0$ and hence, that regarding gender differences

$$
\alpha_{1}=\beta_{1}
$$

In order to test this null hypothesis we run for each survey and country OLS regressions with the dependent variable of pupils' achievement score and explanatory variables on gender and the following socio-economic background characteristics: single parenthood, sibling in family, mother completed upper secondary education, mother completed tertiary education and books in household.

Table A5 in the appendix presents OLS regression results only for the gender coefficient $\left(\beta_{1}\right)$ for all CEE countries covered in the surveys. It can be directly compared with Table 2, that showed bivariate gender differences in achievement $\left(\alpha_{1}\right)$. Results show that gender differences in achievement are now significant for some countries while they were not in the bivariate analysis. Gaps between boys and girls in reading seem to decrease to some extent, while they increase slightly for girls' disadvantage in the subjects maths and science. However, with the exception of Albania we find for all other countries that gender differences between bi- and multivariate results do not differ significantly ${ }^{10}$. Hence, results discussed in previous sections remain largely the same once it is controlled for pupils' socio-economic background.

However, some literature suggests that there is a gender-sensitive impact of educational determinants upon educational success. Gender disadvantage in education might intensify with poverty and social disadvantage (UNESCO 2003a). For several developing countries it has been illustrated, that parents with lower education promote boys' educational attainment more than that of girls while higher educated parents do not differentiate between the genders of their children. The greater predominance and re-emergence of traditional values in Eastern European countries (Inglehard 2003) might have resulted in lower chances of girls in less educated households to be supported by their parents.

The influence of region on educational achievement might be gender sensitive, too. Traditional family roles appear to be predominant especially in rural areas in CEE countries

\footnotetext{
${ }^{10}$ The $\mathrm{t}$-value is calculated by $t=\frac{\alpha_{1}-\beta_{1}}{\text { s.e. }\left(\alpha_{1}-\beta_{1}\right)}$ whereby s.e. $\left(\alpha_{1}-\beta_{1}\right)=\sqrt{\left(s . e\left(\alpha_{1))}\right)^{2}+\left(\text { s.e. }\left(\beta_{1}\right)\right)^{2}-2 \operatorname{COV}\left(\alpha_{1}, \beta_{1}\right)\right.}$
} 
where educational quality is generally worse than in urban areas (UNICEF 2002, World Bank 2000b). Rural areas in especially poor transition countries like Macedonia or Moldova might be characterised by a greater need of girls to assist in the household, to care for younger siblings and to help on the land. Thus, women's education in these areas might be considered as less important than men's.

Hence, the area (AR) and parents' socio-economic status (SE) might impact differently on genders' achievement:

$$
A_{i}=\beta_{0}+\beta_{1} \mathrm{G}_{\mathrm{i}}+\beta_{2} \mathrm{SE}_{\mathrm{i}}+\beta_{3} \mathrm{AR}_{\mathrm{i}}+\beta_{4} \mathrm{SE}_{\mathrm{i}} \mathrm{G}_{\mathrm{i}}+\beta_{5} \mathrm{AR}_{\mathrm{i}} \mathrm{G}_{\mathrm{i}}+\varepsilon_{\mathrm{i}}
$$

In order to measure a gender sensitive impact of the educational determinants we estimate a similar OLS regression model as done before but add three gender interaction variables on education (gender multiplied with mother's education, books in household and area). For the coding of the variables and the variables included in the OLS regression model see Table 4. The control group pupil is male, has a mother who did not complete upper-secondary school, has less than 100 books at home, does not have a sibling and lives in an urban area.

Table 4: Coding of variables

\begin{tabular}{cl}
\hline \hline Variable & Coding of variable \\
\hline Reading test score PISA & PISA reading achievement scores \\
\hline Girl & Boy $=0$, girl=1 \\
\hline Books * gender \\
Monder interaction variables & $\begin{array}{l}\text { Mother education * gender } \\
\text { Area } * \text { gender }\end{array}$ \\
\hline Books in household & $0=0-100$ books, $1=$ more than 100 books \\
Mother above upper secondary & $1=$ mother completed at least upper secondary \\
education & education, $0=$ rest \\
Education missing (edumis) & $0=$ data available, $1=$ data missing \\
Sibling & $0=$ child without siblings, $1=$ other \\
\hline Area & $0=$ urban or suburban, $1=$ rural \\
Area missing & Location missing: 0 if data available, 1 if data \\
missing
\end{tabular}

It is more likely to find a different impact of educational determinants on girls and boys in the survey and measure where gender differences per se are highest than in surveys where gender differences are low or not significant. Hence, Table 5 presents OLS regression results for PISA reading for CEE and a sample of OECD countries. Fields in light grey indicate where gender differences are significant.

We estimated the t-value without taking the covariance into account. Hence, we underestimated the t-value. However, given that both coefficients have very similar values, this might influence the results of a very minor number of countries. 
Table 5 shows that mother's education and books in household is highly correlated with educational achievement for all countries. Pupils who are living in rural areas show generally worse reading achievements than pupils in urban areas. Surprisingly, Macedonia is an exception even though with a very low level of significance. In countries where the variable 'sibling' is significant pupil's achievement is lower if they have a brother or sister living with them at home.

Table 5: PISA reading OLS regressions

\begin{tabular}{|c|c|c|c|c|c|c|c|c|c|c|}
\hline & Albania & Bulgaria & Czech & Hungary & Latvia & Poland & Romania & Russia & Macedonia & OECD \\
\hline Girl & $\begin{array}{c}52.5 \\
(8.1)^{* * * *}\end{array}$ & $\begin{array}{c}34.8 \\
(14.7)^{* *}\end{array}$ & $\begin{array}{c}59.5 \\
(20.2)^{* *} \\
*\end{array}$ & $\begin{array}{c}19.3 \\
(7.7)^{* *}\end{array}$ & $\begin{array}{c}40.8 \\
(11.8)^{* *} \\
*\end{array}$ & $\begin{array}{c}34.6 \\
(11.2)^{* *} \\
*\end{array}$ & $\begin{array}{r}9.9 \\
(7.9)\end{array}$ & $\begin{array}{c}38.8 \\
(7.7)^{* * * *}\end{array}$ & $\begin{array}{c}42.3 \\
(6.6)^{* * * *}\end{array}$ & $\begin{array}{c}26.3 \\
(2.6)^{* * * *}\end{array}$ \\
\hline $\begin{array}{l}\text { Mothers' } \\
\text { education }\end{array}$ & $\begin{array}{c}36.2 \\
(6.2)^{* * * *}\end{array}$ & $\begin{array}{c}35.1 \\
(8.9)^{* * *}\end{array}$ & $\begin{array}{c}73.0 \\
(17.3)^{* *} \\
*\end{array}$ & $\begin{array}{c}32.1 \\
(6.2)^{* * * *}\end{array}$ & $\begin{array}{c}46.1 \\
(7.6)^{* * *}\end{array}$ & $\begin{array}{c}29.6 \\
(7.1)^{* * *}\end{array}$ & $\begin{array}{c}14.2 \\
(7.3)^{*}\end{array}$ & $\begin{array}{c}31.0 \\
(6.1)^{* * * *}\end{array}$ & $\begin{array}{c}75.4 \\
(6.8)^{* * * *}\end{array}$ & $\begin{array}{c}30.6 \\
(2.2)^{* * * *}\end{array}$ \\
\hline $\begin{array}{l}\text { Education* } \\
\text { gender }\end{array}$ & $\begin{array}{l}-4.3 \\
(7.2)\end{array}$ & $\begin{array}{c}4.8 \\
(14.2) \\
\end{array}$ & $\begin{array}{c}-27.6 \\
(15.5)^{*}\end{array}$ & $\begin{array}{l}11.3 \\
(7.6)\end{array}$ & $\begin{array}{c}1.7 \\
(10.9)\end{array}$ & $\begin{array}{l}-4.3 \\
(8.6)\end{array}$ & $\begin{array}{l}14.4 \\
(9.0) \\
\end{array}$ & $\begin{array}{l}-6.8 \\
(7.3)\end{array}$ & $\begin{array}{l}-0.3 \\
(7.0)\end{array}$ & $\begin{array}{c}0.6 \\
(2.2)\end{array}$ \\
\hline $\begin{array}{l}\text { Education } \\
\text { missing }\end{array}$ & $\begin{array}{c}-63.8 \\
(12.1)^{* * *}\end{array}$ & $\begin{array}{c}-2.4 \\
(11.8)\end{array}$ & $\begin{array}{c}-33.5 \\
(15.3)^{* *}\end{array}$ & $\begin{array}{c}-30.3 \\
(12.1)^{* *}\end{array}$ & $\begin{array}{c}-19.2 \\
(9.0) * *\end{array}$ & $\begin{array}{c}-22.0 \\
(8.7)^{* *}\end{array}$ & $\begin{array}{c}-31.0 \\
(14.1)^{* *}\end{array}$ & $\begin{array}{l}-3.1 \\
(4.4)\end{array}$ & $\begin{array}{c}-36.3 \\
(11.0)^{* * *}\end{array}$ & $\begin{array}{c}-33.1 \\
(2.9)^{* * * *}\end{array}$ \\
\hline Books & $\begin{array}{c}51.2 \\
(7.5)^{* * *}\end{array}$ & $\begin{array}{c}52.1 \\
(5.7)^{* * * *}\end{array}$ & $\begin{array}{c}60.9 \\
(7.4)^{* * * *}\end{array}$ & $\begin{array}{c}73.0 \\
(5.7)^{* * * *}\end{array}$ & $\begin{array}{c}52.9 \\
(6.2)^{* * * *} \\
\end{array}$ & $\begin{array}{c}50.0 \\
(7.3)^{* * * *}\end{array}$ & $\begin{array}{c}34.5 \\
(6.1)^{* * * *}\end{array}$ & $\begin{array}{c}47.4 \\
(4.1)^{* * *} \\
\end{array}$ & $\begin{array}{c}15.9 \\
(6.4)^{* *}\end{array}$ & $\begin{array}{c}48.6 \\
(1.6)^{* * * *} \\
\end{array}$ \\
\hline $\begin{array}{l}\text { Books* } \\
\text { gender }\end{array}$ & $\begin{array}{l}-13.5 \\
(8.0)^{*}\end{array}$ & $\begin{array}{c}4.9 \\
(6.1) \\
\end{array}$ & $\begin{array}{l}-3.9 \\
(8.3)\end{array}$ & $\begin{array}{l}-4.2 \\
(6.4) \\
\end{array}$ & $\begin{array}{c}-3.3 \\
(6.8) \\
\end{array}$ & $\begin{array}{c}-0.4 \\
(8.1) \\
\end{array}$ & $\begin{array}{r}-10.2 \\
(9.1)\end{array}$ & $\begin{array}{c}-0.4 \\
(4.3) \\
\end{array}$ & $\begin{array}{l}-3.5 \\
(6.7)\end{array}$ & $\begin{array}{c}-0.1 \\
(1.9)\end{array}$ \\
\hline Sibling & $\begin{array}{c}8.5 \\
(7.4) \\
\end{array}$ & $\begin{array}{c}-10.7 \\
(4.8)^{* *}\end{array}$ & $\begin{array}{c}-18.8 \\
(5.1)^{* * * *}\end{array}$ & $\begin{array}{c}-15.9 \\
(4.0) * * *\end{array}$ & $\begin{array}{l}-9.5 \\
(6.1)\end{array}$ & $\begin{array}{c}-14.0 \\
(6.9) * *\end{array}$ & $\begin{array}{c}-12.7 \\
(3.6)^{* * * *}\end{array}$ & $\begin{array}{c}-20.3 \\
(3.6) * * *\end{array}$ & $\begin{array}{c}0.5 \\
(5.0)\end{array}$ & $\begin{array}{c}-10.1 \\
(1.6)^{* * * *}\end{array}$ \\
\hline Area & $\begin{array}{c}-46.7 \\
(8.2)^{* * * *}\end{array}$ & $\begin{array}{c}-55.0 \\
(12.0)^{* *} \\
*\end{array}$ & $\begin{array}{l}-15.4 \\
(10.5)\end{array}$ & $\begin{array}{c}-31.0 \\
(11.0)^{* *} \\
*\end{array}$ & $\begin{array}{c}-39.2 \\
(10.2)^{* *} \\
*\end{array}$ & $\begin{array}{l}-27.0 \\
(16.6)\end{array}$ & $\begin{array}{c}-57.7 \\
(13.1)^{* * *}\end{array}$ & $\begin{array}{c}-38.2 \\
(7.6)^{* * * *}\end{array}$ & $\begin{array}{c}15.6 \\
(8.8)^{*}\end{array}$ & $\begin{array}{c}-18.2 \\
(2.9)^{* * *}\end{array}$ \\
\hline $\begin{array}{l}\text { Area* } \\
\text { gender }\end{array}$ & $\begin{array}{l}-9.4 \\
(7.5)\end{array}$ & $\begin{array}{c}0.6 \\
(12.8) \\
\end{array}$ & $\begin{array}{l}-4.9 \\
(9.0)\end{array}$ & $\begin{array}{c}6.3 \\
(9.5) \\
\end{array}$ & $\begin{array}{c}18.8 \\
(8.3)^{* * *}\end{array}$ & $\begin{array}{c}4.9 \\
(13.3)\end{array}$ & $\begin{array}{l}-3.9 \\
(9.4) \\
\end{array}$ & $\begin{array}{c}5.5 \\
(5.5)\end{array}$ & $\begin{array}{l}-10.7 \\
(7.9)\end{array}$ & $\begin{array}{c}11.2 \\
(2.5)^{* * * *}\end{array}$ \\
\hline $\begin{array}{l}\text { Area } \\
\text { missing }\end{array}$ & & $\begin{array}{l}24.3 \\
(28.2)\end{array}$ & & $\begin{array}{c}-94.8 \\
(20.3)^{* *} \\
*\end{array}$ & $\begin{array}{c}-21.3 \\
(10.5) * *\end{array}$ & & & & & $\begin{array}{l}-6.0 \\
(5.5)\end{array}$ \\
\hline Constant & $\begin{array}{c}318.5 \\
(11.1)^{* * *}\end{array}$ & $\begin{array}{c}372.4 \\
(11.1)^{* *} \\
*\end{array}$ & $\begin{array}{c}394.4 \\
(24.3)^{* *} \\
*\end{array}$ & $\begin{array}{c}418.5 \\
(7.7)^{* * * *}\end{array}$ & $\begin{array}{c}386.7 \\
(13.4)^{* *} \\
*\end{array}$ & $\begin{array}{c}439.2 \\
(11.0)^{* *} \\
*\end{array}$ & $\begin{array}{c}425.1 \\
(7.4)^{* * *}\end{array}$ & $\begin{array}{c}426.3 \\
(7.7)^{* * *}\end{array}$ & $\begin{array}{c}304.1 \\
(7.3)^{* * * *}\end{array}$ & $\begin{array}{c}469.4 \\
(3.2)^{* * *}\end{array}$ \\
\hline Obs. & 4456 & 4317 & 5311 & 4744 & 3777 & 3474 & 4731 & 6578 & 4201 & 62196 \\
\hline $\mathrm{R}^{2}$ & 0.32 & 0.23 & 0.22 & 0.30 & 0.20 & 0.16 & 0.16 & 0.21 & 0.26 & 0.16 \\
\hline
\end{tabular}

Note: standard errors taking survey design into account (svyreg command in Stata 8.0) in parentheses, * significant at $10 \%$; ** significant at $5 \% ; * * *$ significant at $1 \%$; fields in grey show a significant different between genders.

As expected, the gender coefficient is highly significant for all countries and similar to uncontrolled results given in Table 2. However, in contrast to our expectations there is generally no significant impact of gender interaction variables on educational achievement with the exception of four cases. In the Czech Republic gender differences between children with mothers' lower educational background are higher than those of children with mothers' higher educational background. The same relation appears for Albania regarding the variable 'books in household'. Even though the significance of this 'effect' is low (10 percent level) in both countries a tendency might exist that higher socio economic background leads to 
mitigated gender differences in achievement probably due to better educated parents' efforts to promote boys' reading skills. ${ }^{11}$

The relation of area and gender matters only for Latvia and OECD countries as a whole. For both the negative impact of pupils' rural catchment area on educational achievement is mitigated by almost a half, if it is female students who live in rural areas.

However, in general determinants of educational achievement are not gender sensitive. This does not necessarily contradict literature that assumes that socio-economic background impacts differently on boys' and girls' achievement in transition countries. Our coverage of post-communist countries excludes the Caucasus and Central Asia, where different economic, cultural and geographic environments might determine gender variance in educational achievement much more pronouncedly than in those countries covered by the three surveys.

\section{$7 \quad$ Conclusion}

The paper examined two questions:

1. Do surveys show robust results regarding gender differences in educational achievement?

Results indicate a relative even though not complete agreement on gender equality in educational achievement between surveys. Correlation of countries' gender achievement gaps is moderate with correlation coefficients of 0.6 for the same subjects between surveys. Surveys agree also regarding clear patterns on gender equality for some countries. For example, consistently girls' advantage in reading is the lowest and boys' advantage in maths and science is the highest compared to all other transition countries in the Czech Republic. On the other hand, Romania shows very small gender inequalities throughout all surveys. Also the comparison of gender gaps in achievement across the whole achievement distribution shows similar patterns for surveys that cover the same subject.

2. Does gender balance in educational access translate into gender equality in educational achievement?

The answer is clearly no.

PIRLS and PISA data reveal consistently a great disadvantage of boys in reading achievement. Even though boys show partly better results for the subjects science and maths for some surveys and countries, the female advantage in reading is much more predominant and great if expressed in grade progression or absolute educational advantage.

\footnotetext{
${ }^{11}$ However, regression results for PIRLS data do not confirm this result for the Czech Republic (not shown). Albania is not covered by PIRLS.
} 
Boys' lower average achievement in reading is concerning since it is a result of very low achieving boys at the bottom of the achievement distribution. Worst performing boys show considerably lower achievement scores than worst performing girls in reading. This indicates that boys situated at the bottom of the achievement distribution might face serious problems in catching up with girls regarding their reading skills. On the other hand, if girls show on average lower achievement than boys in science and math, this can be greatly explained by boys' bigger advantage at the top of the achievement distribution.

These results refer to bivariate analysis, but we explained and showed that by controlling for pupils' socio-economic status results on gender inequality do generally not change. In addition, gender inequalities in educational achievement seem generally not to be greater in rural areas or in families with lower socio-economic background in those transition countries covered by the surveys.

The great advantage of girls over boys regarding educational achievement in CEE countries is surprising after 10 years of transition that is often believed to have favoured the male population. It is even more striking once we compare OECD with transition countries. Regarding the subjects maths and science transition countries seem to be even more successful than OECD countries in limiting girls' educational disadvantage compared to boys and hence are more successful in maintaining gender equality in educational achievement. In addition, in reading achievement girls' educational advantage seems to be even greater in CEE than in OECD countries regarding the survey PISA.

Nevertheless, conclusions on gender equality in educational achievement for transition countries need to be drawn carefully since our analysis did not cover countries in Central Asia and the Caucasus that are very different in terms of economic, geographic and cultural background than the set of transition countries analysed here.

Even if the general results of this paper must lead to a concern regarding boys' abilities and not that of girls' the paper is limited in its approach by focusing only on gender equality in educational achievement and not on gender equality in educational outcomes. There is further need to examine whether women and men with equal educational achievement face equal opportunities of using their human capital and gaining from it in transition countries. There is some evidence for Western industrialised countries that women fare worse even though their skills are higher (Leslie 2003). Also in transition countries there are many indicators like gender pay gaps and occupational segregation indicating that even 
though women are better qualified they are very likely to face discrimination in the labour market. 


\section{Appendix}

Table A1: Female-to-male ratio of net enrolment for primary, secondary and tertiary education in 2000

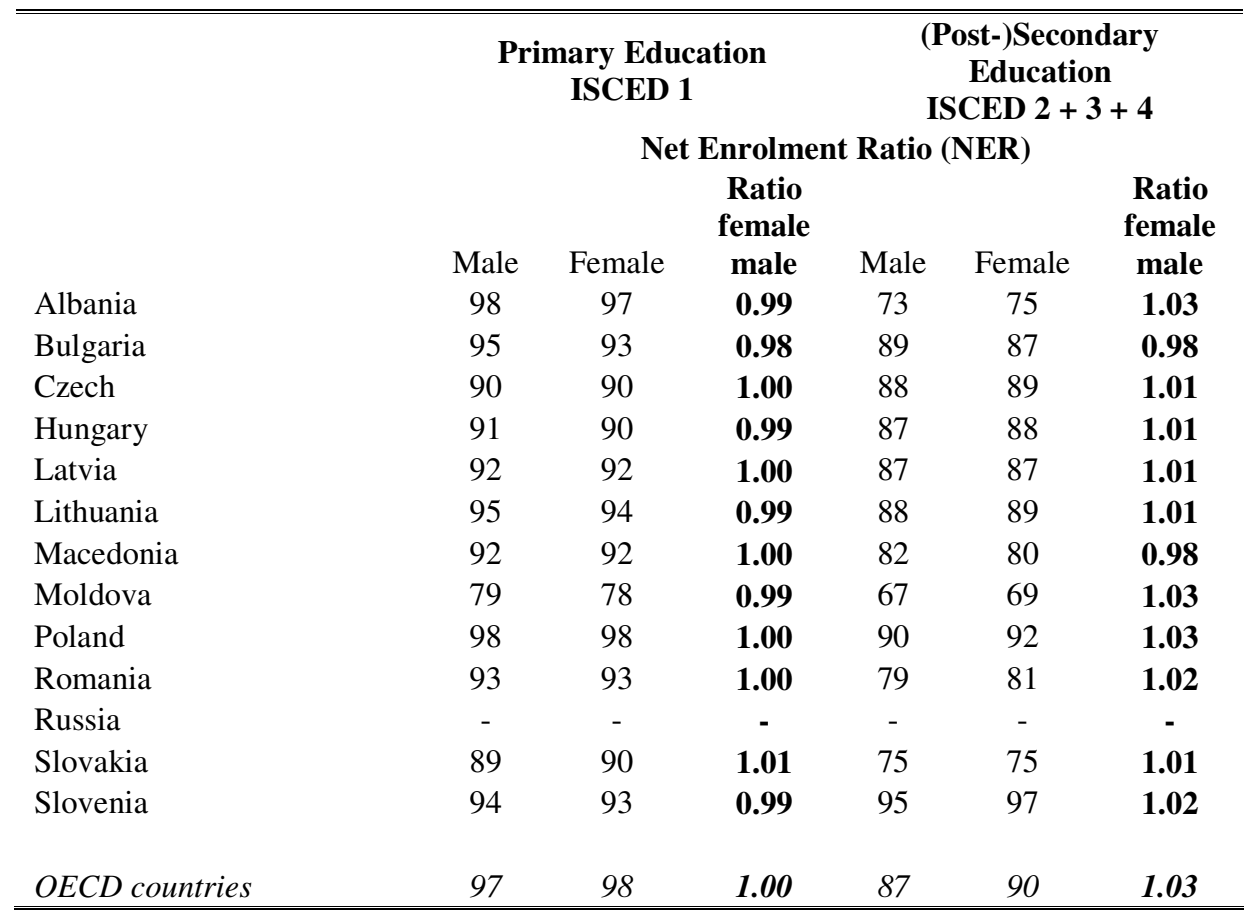

Source: UNESCO 2003a, UNESCO 2003b, author's calculations. Note: OECD countries refer to Austria, Australia, Denmark, Finland, France, Germany, Greece, Iceland, Italy, Luxembourg, Netherlands, New Zealand, Mexico, Norway, Spain, Sweden, UK and USA. Eastern Europe averages without Russia. Regional values refer to the mean value of the country group.

Table A2: Correlation matrix of gender differences for OECD and CEE countries between surveys

\begin{tabular}{llcccccc}
\hline \hline & & \multicolumn{2}{c}{ Reading } & \multicolumn{2}{c}{ Maths } & \multicolumn{2}{c}{ Science } \\
& & PISA & PIRLS & PISA & TIMSS & PISA & TIMSS \\
\hline Reading & PISA & 1 & & & & & \\
& PIRLS & $\mathbf{0 . 6 4 5}$ & 1 & & & & \\
Maths & PISA & 0.588 & 0.505 & 1 & & & \\
& TIMSS & 0.311 & 0.324 & $\mathbf{0 . 5 8 7}$ & 1 & & 1 \\
\hline \hline
\end{tabular}

Note: Gives correlation coefficient for all OECD and CEE countries covered by both surveys correlated. 
Table A3: Gender differences in surveys' mean achievement expressed in years of schooling retreat

\begin{tabular}{|c|c|c|c|c|c|}
\hline & $\begin{array}{c}\text { PISA } \\
\text { Reading }\end{array}$ & $\begin{array}{l}\text { TIMSS } \\
\text { Maths }\end{array}$ & $\begin{array}{l}\text { PISA } \\
\text { Maths }\end{array}$ & $\begin{array}{c}\text { TIMSS } \\
\text { Science }\end{array}$ & $\begin{array}{c}\text { PISA } \\
\text { Science }\end{array}$ \\
\hline Albania & 1.0 & na & 0.4 & na & 0.5 \\
\hline Bulgaria & ns grade diff & ns & ns & no data grade & ns \\
\hline Czech Republic & 1.8 & 0.5 & ns grade diff & 1.0 & ns \\
\hline Hungary & 0.9 & ns & ns & 0.8 & ns \\
\hline Latvia & 1.2 & ns & ns & 0.3 & 0.7 \\
\hline Lithuania & na & ns & na & 0.3 & na \\
\hline Macedonia & 1.6 & ns & ns & ns & 0.7 \\
\hline Moldova & ns & ns & na & ns & na \\
\hline Poland & no data grade & na & ns & na & $\mathrm{ns}$ \\
\hline Romania & 0.2 & ns & na & ns & 0.2 \\
\hline Russia & 1.5 & ns & ns & 0.4 & 0.7 \\
\hline Slovakia & na & ns & na & 0.7 & na \\
\hline Slovenia & na & ns & na & 0.5 & na \\
\hline
\end{tabular}

Note: Numbers show the years of schooling the disadvantage gender is behind the advantaged gender. Light grey fields show year advantages of females, dark grey fields show year advantages of males. Years are calculated by dividing gender differences in mean scores of country by the difference in learning achievement between the lower and upper grade of the country for each survey. "na" means country not administered in survey. "ns" mans that gender differences are not significant. "ns grade diff" means grade difference in meaning achievement is not significant. "no data grade" means that a too small number of students participated in two comparable grades. Data for TIMSS refer to 1995 (since grade differences can be calculated only for this year). PIRLS survey not included because no sufficient data on grades $^{12}$.

Table A4: Percentage of pupils below PISA reading level 2 by gender

\begin{tabular}{lccc}
\hline \hline & \multicolumn{3}{c}{ PISA reading 15 year-olds } \\
$\begin{array}{l}\text { Absolute } \\
\text { measure }\end{array}$ & \multicolumn{3}{c}{ below PISA reading level 2 } \\
& male & female & $\begin{array}{c}\text { Ratio } \\
\text { male/female }\end{array}$ \\
Albania & 80.60 & 60.40 & 1.33 \\
Bulgaria & 50.30 & 29.80 & 1.69 \\
Czech Rep. & 23.60 & 11.50 & 2.05 \\
Hungary & 27.20 & 17.90 & 1.52 \\
Latvia & 40.70 & 20.30 & 2.00 \\
Macedonia & 72.30 & 52.20 & 1.39 \\
Poland & 30.40 & 15.90 & 1.91 \\
Romania & 44.20 & 38.60 & 1.15 \\
Russia & 35.10 & 19.70 & 1.78 \\
\hline \hline
\end{tabular}

Source: OECD 2003, own calculations.

\footnotetext{
${ }^{12}$ Students in the PIRLS sample attended all the same grade (the grade where most of 9th graders were situated). It is possible to calculate mean achievement differences between younger and older children in the same grade. However, these achievement differences were not significant for most of the countries and showed, that often younger children performed better than older children. This is probably due to the selection of the sample, where older children might attend classes where mostly younger children are situated due to lower achievement. However, in contrast to PISA data where achievement differences between the lower and upper grade was almost always highly significant the PIRLS data refers to much younger children, where in general learning differences might not be so different between different ages.
} 
Figure A1: Ratio of achievement scores of boys to girls by percentile for PISA maths

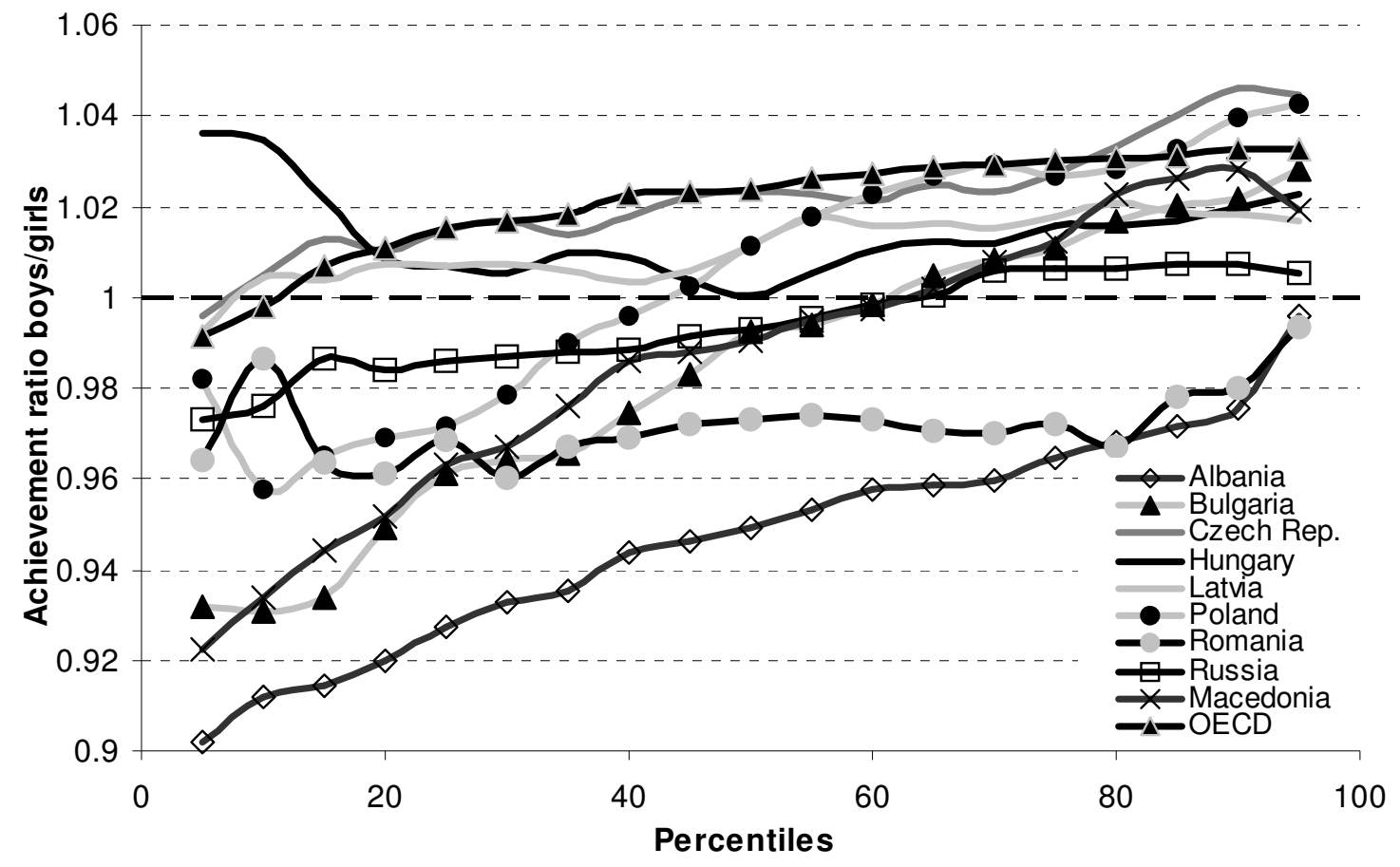

Table A5: gender coefficient for each survey and subject if controlled for children's socio-economic background derived from OLS regression analysis conducted equally for each survey and subject

\begin{tabular}{|c|c|c|c|c|c|c|}
\hline & $\begin{array}{c}\text { PISA } \\
\text { Reading }\end{array}$ & $\begin{array}{l}\text { PIRLSs } \\
\text { Reading }\end{array}$ & $\begin{array}{l}\text { PISA } \\
\text { Maths }\end{array}$ & $\begin{array}{l}\text { TIMSS } \\
\text { Maths }\end{array}$ & $\begin{array}{c}\text { PISA } \\
\text { Science }\end{array}$ & $\begin{array}{l}\text { TIMSS } \\
\text { Science }\end{array}$ \\
\hline Albania & $-43.9(3.3)$ & & $-1.0(4.3)$ & & $-12.7(4.2)$ & \\
\hline Latvia & $-50.1(3.9)$ & $-19.0(1.9)$ & 7.4 & $9.3(3.3)$ & $-19.3(4.3)$ & $19.1(2.8)$ \\
\hline Macedonia & $-41.7(4.3)$ & $-23.1(3.2)$ & $6.9(4.5)$ & & $-7.7(4.0)$ & \\
\hline Bulgaria & $-38.6(4.6)$ & $-20.6(2.3)$ & $11.0(5.5)$ & $3.8(4.1)$ & $0.5(4.6)$ & $17.4(4.3)$ \\
\hline Moldova & & $-23.2(2.3)$ & & $4.2(2.7)$ & & $11.7(3.0)$ \\
\hline Lithuania & & $-15.0(2.2)$ & & & & \\
\hline Russia & $-34.8(2.7)$ & $-11.4(1.8)$ & $2.4(4.0)$ & $4.6(2.8)$ & $-11.2(3.7)$ & $24.0(3.1)$ \\
\hline Czech Republic & $-26.7(3.5)$ & $-11.6(2.1)$ & $20.6(4.2)$ & $16.7(3.4)$ & $10.6(4.0)$ & $33.3(3.3)$ \\
\hline Poland & $-29.8(6.3)$ & & $10.6(8.3)$ & & $12.1(6.3)$ & \\
\hline Hungary & $-28.7(3.8)$ & $-15.8(1.6)$ & $10.1(4.4)$ & $8.4(2.7)$ & $-0.1(4.8)$ & $25.9(2.7)$ \\
\hline Romania & $-13.7(4.8)$ & $-16.9(2.5)$ & $-10.1(5.3)$ & $-1.6(3.4)$ & $-14.7(5.1)$ & $10.2(4.3)$ \\
\hline Slovakia & & $-14.0(1.9)$ & & $8.3(2.8)$ & & $24.3(3.1)$ \\
\hline Slovenia & & $-22.1(2.3)$ & & $2.1(3.0)$ & & $13.5(2.7)$ \\
\hline
\end{tabular}

Source: author's calculations. Standard errors are given in parentheses. Clustering of schools and weighting taken into account for estimation of standard errors (svyreg command in Stata). Grid lines (Albania) show where significant difference between gender differences to Table 3 (crude gender differences in mean achievement). For all surveys it was controlled for the following independent variables of children's socio-economic background: single parenthood, sibling, mother secondary education, mother tertiary education and books in household. For Lithuania and Macedonia in TIMSS no data on some of the SE variables were available. 


\section{Differences of coding of variables between surveys for OLS regressions}

Mother's upper secondary education refers to ISCED levels 3a, 3b, 3c, 4a and 4b for PIRLS (interviewee was not the child like in TIMSS and PISA but an adult household member). Secondary education refers to ISCED levels $3 a, 3 b, 3 c$ for PISA and to "finished secondary" and "some vocational education". TIMSS data refer to secondary education and not to upper secondary education.

Mother's tertiary education refers to ISCED levels 5a and 5b for PIRLS, to a yes to the question "Does your mother have tertiary education" in PISA and to "some university" and "finished university" for TIMSS.

Regression analysis in Table 5 combines the two dummy variables mothers' upper secondary and tertiary education into one.

Single parenthood means for TIMSS and PISA that only one of the following persons live at home with the child: mother, father, female guardian, male guardian. For PIRLS single parenthood is equal to single adulthood, since only one adult lives with the child together. 


\section{References}

E. Brainerd (2000), 'Women in Transition: Changes in Gender Wage Differentials in Eastern Europe and the Former Soviet Union', Industrial and Labour Relations Review, 54 (1), 138162.

G. Brown and J. Micklewright (2004), 'Using International Surveys of Achievement and Literacy: A View from the Outside', UNESCO Institute for Statistics working paper, Montreal, forthcoming.

L. Hedges and L. Friedman (1993), 'Gender differences in variability in intellectual abilities: A reanalysis of Feingold's results', Review of Educational Research, 63,pp. 94-105.

L. Hedges and A. Nowell (1995), 'Sex Differences in Mental Test Scores, Variability, and Numbers of High Scoring Individuals', Science, 269, pp. 41-45.

R. Inglehart and P. Norris (2003), Rising Tide: Gender Equality \& Cultural Change Around the World, Cambridge University Press.

B. Laporte and J. Schweitzer (1994), 'Education and Training', in: Barr, N.: Labor Markets and Social Policy in Central and Eastern Europe.

D. Leslie 2003, 'Better qualified but a lower acceptance rate: does higher education discriminate against women?', http://repec.org/res2003/Leslie.pdf

Micklewright and Schnepf (2004), 'How good is education in Central and Eastern European countries', Applications and Methods Working Paper A04/X, Southampton Statistical Sciences Research Institute, University of Southampton, forthcoming.

I. Mullis, M. Martin, E. Gonzales and A. Kennedy (2003), PIRLS 2001 International Report, Boston College.

I. Mullis, M. Martin, E. Gonzalez, K. Gregory, R. Garden, K. O'Connor, S. Chrostowski, T. Smith (2000a), TIMSS 1999 International Mathematics Report, Boston College.

I. Mullis, M. Martin, Fierros, Goldberg, Stemler (2000b), Gender Differences in Achievement, Boston College.

A. Newell (2001), The Distribution of Wages in Transition Countries, www.sussex.ac.uk/Units/economics/dp/Newell4.pdf

OECD (2001), Knowledge and Skills for Life - First results from PISA 2000, OECD, Paris.

OECD (2002), Technical Report for PISA, OECD, Paris.

OECD and UNESCO Institute for Statistics (2003), Literacy Skills for the World of Tomorrow - Further results from PISA 2000, OECD, Paris.

A. Pailhe (2000), 'Gender Discrimination in Central Europe during the systemic transition', Economics of Transition, Volume 8, No. 2 
A. Tablyshalieva (1999), 'Revival of Traditions in Post-Soviet Central Asia', in M. Lazreg Making the Transition Work for Women in Europe and Central Asia, World Bank Discussion Paper No. 411.

UNESCO (2003a), EFA Global Monitoring Report on Gender Inequalities in Education

UNESCO (2003b), Global Education Digest 2003. Comparing Education Statistics Across the World, UNESCO.

UNICEF (1999), Women in transition, Regional Monitoring Report, No. 6, UNICEF Innocenti Research Centre, Florence.

UNICEF (2002), A League Table of Educational Disadvantage in Rich Nations, Innocenti Report Card 4, UNICEF Innocenti Research Centre, Florence.

UNICEF (2002), A Decade of Transition, Regional Monitoring Report, No.8, UNICEF Innocenti Research Centre, Florence.

World Bank (2000a): Making Transition Work for Everyone. Poverty and Inequality in Europe and Central Asia, Washington D.C.

World Bank (2000b): Hidden Challenges to Education Systems in Transition Economies, Washington D.C. 